\title{
Ecology and conservation of the polecat Mustela putorius (Linnaeus, 1758) in Portugal: a review
}

\author{
Ecología y conservación del turón Mustela putorius \\ (Linnaeus, 1758) en Portugal: una revisión

\section{Mustela putorius (Linnaeus, 1758) ipurtatsaren ekologia eta kontserbazioa Portugalen: berrikuspen bat}

\author{
Mafalda Costa ${ }^{1,2^{\star}}$, Carlos Fernandes ${ }^{1}$ \& Margarida Santos-Reis ${ }^{1}$ \\ ${ }^{1}$ Centro de Biologia Ambiental, Faculdade de Ciências da Universidade de Lisboa, Portugal \\ ${ }^{2}$ OnE - Organisms and Environment Division, School of Biosciences, Cardiff University, Wales, United Kingdom \\ *Corresponding author: CostaMB@cardiff.ac.uk
}

\begin{abstract}
In Portugal, the current status of the European polecat Mustela putorius (Linnaeus, 1758) is Data Deficient but, although apparently widespread in the country, empirical evidence suggests a population decline. The present review summarises information from published studies and grey literature concerning the species' distribution, ecological requirements and the negative impacts of anthropogenic pressures. In southern Portugal, polecats seem to be strongly associated with riparian habitats and specialised in the consumption of lagomorphs. Main threats to the species in Portugal are habitat degradation due to agricultural intensification, decline of prey populations, direct persecution, and road mortality. Further research is urgently needed to accurately map the occurrence of the polecat and assess the current trend of its populations, so that conservation and management actions can be properly applied. Ongoing studies are expected to provide new insights into patterns of time and space use, genetic structure and putative hybridisation with domestic ferrets, and interspecific interactions with the other semi-aquatic carnivores of the Portuguese fauna, the otter Lutra lutra (Linnaeus, 1758) and the American mink Neovison vison (Schreber, 1777). Conservation actions should include the recovery and preservation of the habitats for polecats and their prey, promotion of non-intensive farming and restricted use of pesticides, surveillance of predator control activities, enforcement of mitigation measures in human-altered landscapes, and monitoring of hybridisation with ferrets. The implementation of these measures should increase polecat chances of persisting in Portuguese landscapes and, ultimately, would benefit the whole carnivore community.
\end{abstract}

KEY WORDS: European polecat, ecology and conservation, literature review, Mustela putorius, Portugal.

\section{RESUMEN}

La información actual sobre el estado del turón Mustela putorius (Linnaeus, 1758) en Portugal es escasa; sin embargo, a pesar de que parece estar ampliamente distribuido por todo el país, evidencias empíricas parecen indicar un disminución de la población. La presente revisión es un compendio de toda la información disponible en artículos y literatura gris sobre su distribución, ecología y el impacto que la actividad humana ha ejercido sobre la especie. En el sur de Portugal, el turón parece estar fuertemente asociado a zonas ribereñas y haberse especializado en el consumo de lagomorfos. Las principales amenazas a esta especie en Portugal son la degradación de su hábitat debido a la intensificación de la agricultura, la disminución de las poblaciones de sus presas, la persecución directa de animales, y la muerte accidental en carreteras. Por lo tanto, es necesaria más investigación que permita determinar la incidencia y tendencias de las poblaciones de turón, con el fin de poder aplicar e implementar eficazmente diferentes programas de conservación y gestión. Se espera que los estudios en curso puedan contribuir con informaciones relevantes hacia los patrones de utilización del espacio y tiempo por esta especie, su estructura genética, la posible hibridación con hurones domésticos y la interacción específica con las otras especies de carnívoros semiacuáticos de la fauna portuguesa, la nutria Lutra lutra (Linnaeus, 1758) y el visón americano Neovison vison (Schreber, 1777). Las acciones de conservación del turón deben incluir la recuperación de su hábitat y el de sus presas; así mismo, es necesario el fomento de una agricultura no intensiva, que conlleve a una reducción del uso de plaguicidas, así como una estricta vigilancia sobre el control de depredadores, el refuerzo sobre las medidas de mitigación en paisajes alterados por el hombre, y el monitoreo de la hibridación con los hurones. La implementación de estas medidas debería incrementar las posibilidades de supervivencia de los turones en Portugal, así como beneficiar la comunidad carnívora en general.

PALABRAS CLAVE: Turón europeo, ecología y conservación, revisión literaria, Mustela putorius, Portugal

\section{LABURPENA}

Une honetan Mustela putorius (Linnaeus, 1758) ipurtatsaren Portugalgo egoeraren inguruan dugun informazioa urria da. Hala ere, herrialde osoan nahiko zabalduta dagoela dirudien arren, badirudi ebidentzia enpirikoen arabera, populazioa txikitu egin dela. Artikuluetan eta literatura grisean espezie honen banaketari, ekologiari eta giza jarduerek ekarri dioten eraginari buruz eskuragarri dagoen informazio guztia laburbildu dugu berrikuspen honetan. Portugal hegoaldean, badirudi ipurtatsa urbazterreko eremuei oso lotuta dagoela eta lagomorfoen kontsumoan espezializatu dela. Espezie honek Portugalen dituen mehatxu nagusiak nekazaritza-jarduerak areagotzeak ekarritako habitaten degradazioa, harrapakinen populazioak urritzea, animalien zuzeneko jazarpena eta errepideetan istripuz hiltzea dira. Beraz, beharrezkoa da ikerketa gehiago egitea ipurtatsaren populazioen intzidentzia eta joerak ezagutzeko, kontserbaziorako eta kudeaketarako programak eraginkortasunez aplikatu eta ezarri ahal izateko. Espero dugu abian diren azterlanek lagunduko dutela espezie honen inguruan informazio garrantzitsuak lortzen honako arlo hauei buruz: espazioaren eta denboraren erabilerari buruzko ereduak, egitura genetikoa, etxeko hudoekin izan ditzakeen hibridazioak eta Portugalgo faunako beste espezie haragijale erdi-urtarrekin, Lutra lutra (Linnaeus, 1758) igarabarekin eta Neovison vison bisoi amerikarrarekin (Schreber, 1777) duen interakzio espezifikoa. Ipurtatsaren kontserbaziorako ekintzen artean sartu behar dira habitata eta harrapakinak berreskuratzea. Horrez gain, beharrezkoa da nekazaritza ez-intentsiboa sustatzea eta horrela, pestiziden erabilera murriztea, harraparien kontrola zorrotz zaintzea, gizakiak eraldatutako paisaietan arintze-neurriak indartzea eta hudoekin dituzten hibridazioak monitorizatzea. Neurri horiek ezartzeak handitu egingo lituzkete ipurtatsek Portugalen bizirauteko dituzten aukerak eta haragijaleen komunitateari, oro har, mesede egingo lioke. 


\section{INTRODUCTION}

The European polecat Mustela putorius (Linnaeus, 1758 ) is one of the least known carnivore species in Portugal, with the available information being scarce and scattered in time and space. Few studies have been conducted in the country since the first review of the species status, distribution and ecology, made by Santos-Reis (1983). This was based on historical references (e.g. Vandelli, 1787; Bocage, 1863; Seabra, 1900), personal observations of museum specimens and of living animals or their signs of presence in the field. Here we revisit the knowledge on the species, summarising data from both peer-reviewed papers and grey literature (e.g. unpublished theses, technical reports) produced in the last three decades, of what we currently know about the polecat in Portugal. In total, we were able to gather 35 documents that contained information about the species, ranging from historical distributional observations to recent ecological data on feeding habits and habitat requirements, and threats to the species survival in the country.

This review is organised in three main sections: the first is an overview of the species' current distribution and trends; the second summarises ecological data and conservation issues; and finally the third discusses current knowledge gaps, research needs and provides several conservation guidelines.

\section{DISTRIBUTION AND STATUS}

Data gathered by Santos-Reis (1983) confirmed the presence of the polecat all over the country. However, in the absence of national or regional surveys and due to the elusive, solitary and nocturnal habits of the species, population size and status could not be ascertained. Although scattered information continued to be accumulated in the following years, in the absence of specific work the species was classified as Insufficiently Known $(K)$ in the Portuguese Red Data Book (SNPRCN, 1990). The polecat is not present in the Portuguese archipelagos of the Azores and Madeira, but its domestic form, the ferret Mustela furo (Linnaeus, 1758), has been introduced there, possibly in the 15th century, with the purpose of hunting wild rabbits Oryctolagus cuniculus (Linnaeus, 1758); some ferrets escaped during the game season and established feral populations, which in the absence of competitors thrive in the wild (Santos-Reis \& Mathias, 1996; Mathias et al., 1998).

In view of the scarcity of data, the Institute for Nature Conservation (ICN), the governmental body responsible for nature conservation and biodiversity policies in the country, promoted a survey in 2003 to clarify the species distribution and trends. Due to financial, time and logistic constraints it was decided to confine the survey area to the centre and north of the country, so as to make it concurrent with the survey of another largely unknown mustelid in Portugal - the pine marten Martes martes (Linnaeus, 1758). Written questionnaires were sent to municipalities and hunting associations (>3,500). Response rate was within normal values for the method ( $30 \%)$ and, despite the recognised uncertainty in this kind of data, a generalised distribution of the polecat but also a declining trend was indicated (Matos \& Santos-Reis, 2003), in agreement with what had been previously suggested by Santos-Reis \& Mathias (1996).

Despite Red Data Book recommendations (SNPRCN, 1990), knowledge on the distribution and status of the polecat in Portugal has remained essentially the same and except for the ICN survey, no monitoring effort has been made to map the species distribution in the country. Hence, the recent review of the species' status (2nd Edition of the Vertebrates Red Data Book - Cabral et al., 2005) only added some new information from unpublished technical reports. This mostly consisted of presence-absence data obtained by monitoring studies of the carnivore fauna in protected areas (e.g. Florêncio, 1993; Chambel et al., 2001) or from monitoring studies under the frame of Environmental Impact Assessments (EIA) (e.g. Santos-Reis et al., 1999; Matos et al., 2001). The majority of these studies had few or no records of polecat's presence, even in areas in which the species had been previously reported (Florêncio, 1993; Chambel et al., 2001). This might be a consequence of low densities or due to methodological biases since most of these studies were aimed at the whole mammalian community and not specifically oriented towards polecat detection. Therefore, Cabral et al. (2005) considered the species' status as Data Deficient (DD) and made new recommendations for an urgent clarification of its distribution and current trends using a standardised strategy and more accurate survey methods.

It is known that non-standardised methods can produce biased descriptions of a species' distribution and abundance by failing to detect the target species, particularly in small populations, due to either low detection rates or insufficient sampling effort (Gu \& Swihart, 2004). Also, large scale surveys using non-systematic sampling for mapping species distribution may result in a misleading representation of a species' range and niche preference, as samples tend to be collected from relatively accessible locations near roads, urban settlements and rivers (Syfert et al., 2013). This was observed in studies of mammalian communities carried out within natural areas in the centre (Beja et al., 2005; Loureiro et al., 2007) and north (Paupério et al., 2008) of Portugal, which underlined the importance of using species-oriented methodologies to avoid sub-estimation of polecat distribution and local abundance.

Mestre et al. (2007) published the first contribution to understand polecat distribution in the Mediterranean agricultural landscapes of Alentejo (southern Portugal). Polecat presences (mostly originated from signs and scent stations) represented just $15 \%$ of the 220 sampled cells $(1 \times 1 \mathrm{~km})$, indicating a scattered spatial pattern despite the fact that more than $50 \%$ of the area had a moderate to high suitability for the species. Still in Alentejo, Santos et al. (2008) investigated the status of threatened carnivores in the context of the construction of the largest dam in Europe (Alqueva, southeast Portugal) and also found a low polecat detection rate in the pre-dam situation, compatible with a fragmented population, likely to have been 
aggravated with the construction and flooding of the reservoir. Beja et al. (2009), in an assessment of predator response to game management, compared 12 game estates and 12 non-hunting areas and only detected the presence of polecat in a single area.

Studies on vertebrate road mortality in southern Portugal showed that polecat road-kills are less frequent than other carnivore species (Grilo et al., 2007, 2009; Carvalho \& Mira, 2010). In a two-year study, involving $260 \mathrm{~km}$ of highways and $314 \mathrm{~km}$ of national roads, Grilo et al. (2009) found that only $2.5 \%$ out of 806 detected casualties of carnivores were of polecats and suggested that this might be positively correlated with the species abundance in the region. This conclusion agrees with both Grilo et al. (2008), in which from a total of 1,940 track records of carnivores detected in highway culverts and underpasses (marble dust track pads) only one corresponded to a polecat, and Mateus et al. (2010), a study conducted in the same area, to assess cost-effectiveness of monitoring methods of carnivore use of drainage culverts, in which not a single polecat was recorded.

A recent study conducted in northwest Portugal investigated the distribution of the American mink Neovison vison (Schreber, 1777) and its interaction with native riparian carnivores, the otter Lutra lutra (Linnaeus, 1758) and the polecat (Rodrigues et al., 2014). Using track-recording rafts and genetic analyses of scats, it found that at a regional scale only $1.5 \%$ out of 270 genetically identified scats were from polecat. At a local scale (Área Protegida da Lagoa de Bertiandos e São Pedro d'Arcos), no evidence of polecat presence was found in 222 carnivore scats genetically assigned to species.

Data from studies based on field signs should be taken cautiously. Polecat footprints are difficult to distinguish from those of mink and are identical to those of the ferret (Blandford, 1987). The same applies to scats, which can be easily mistaken with the ones from those two species or of other mustelids (e.g. Martes foina (Erxleben, 1777) Monterroso et al., 2013). As exemplified by Rodrigues et al. 2014), parallel genetic identification of scats should thus be conducted to increase the confidence of species assignment. Species-specific molecular markers have been developed for non-invasive studies of Iberian carnivores (e.g. Fernandes et al., 2008a; Oliveira et al., 2010). While these markers distinguish polecats from other carnivores, they are unable to discriminate polecat from ferret samples. Despite this shortcoming, it is unlikely that polecat records in mainland Portugal are significantly biased by the presence of ferrets in the wild, as in the road-kill data we have been collecting since 2000 in southern Portugal roads, only $5.6 \%$ out of 71 polecat/ferret samples corresponded genetically to ferrets (Costa et al., unpubl.).

In conclusion, the results of the studies reviewed above are all consistent with the notion that the polecat, although present from north to south, occurs discontinuously and at low densities. If this pattern is a consequence of a declining trend or a long-standing si- tuation is difficult to ascertain due to a lack of sound historical information. Nevertheless, population declines have been documented elsewhere (e.g. in Spain - Virgós, 2002, 2003). In any case, these findings are in disagreement with the species status at the European level - Least Concern (LC) (Fernandes et al., 2008b), even if the species benefits of legal protection due to its listing in the Appendix III of the Bern Convention (European Council 1979) and in the Annex V of the EU Habitats \& Species Directive (1992).

\section{ECOLOGY AND CONSERVATION \\ Ecological requirements}

In Portugal, the ecology of the polecat is still poorly understood and, despite being one of the target species in several carnivore surveys, the small number of records generally precluded further analyses (e.g. Matos et al., 2009; Pita et al., 2009). Exceptions are the studies of Mestre et al. (2007) and Santos et al. $(2008,2009)$ that were species-oriented. The first studied the species' ecological requirements and identified landscape diversity, length of water courses, and number of scrubland and water surface patches, as the main habitat features responsible for the polecat distribution pattern observed in the agricultural landscapes of Alentejo. According to this study, polecat presence seems to be strongly associated with riparian habitats and small scrubland patches. Nevertheless, the authors remark that the animals show habitat plasticity and might be using watercourses as a last-resource shelter, due to the lack of vegetation cover in the surrounding landscape matrix. Association with riparian habitats was also observed by Manghi et al. (2005) who investigated activity patterns and home range sizes of radio-tracked polecats ( 1 adult male, 1 juvenile male and 1 adult female) in a 'montado' (Quercus suber L.) area in Alentejo; results indicated nocturnal activity, with individuals frequently resting during daytime in wild rabbits' burrows, and the use of linear structures, particularly riparian vegetation along stream and lagoon margins, as movement corridors between forested and cultivated habitat patches, The preference for riparian habitats has been formerly described (Blandford, 1987; Lodé, 1993, 1994; Zabala et al., 2005; Rondinini et al., 2006) and its importance seems to increase in fragmented landscapes, either by providing refuge and food resources or by functioning as ecological corridors that enhance connectivity between landscape patches (Virgós, 2001; Matos et al., 2009). Santos et al. (2008) found that polecats in the Alqueva pre-dam situation were also associated with oak woodlands and cereal plantations, the dominant habitats in the area. The same study suggested that in Mediterranean woodlands, polecats seem to alter their habitat selection pattern according to habitat availability, and possibly also in response to the presence of alternative prey, and these conclusions are consistent with previous findings (Lodé, 1994). For instance, in eastern Spain, montane pine forests appear to be the preferred habitat for polecats, with only $33.3 \%$ out of 21 records situating 
polecats near watercourses (Virgós, 2003), whereas in central Spain, in an area dominated by dry crops and uncultivated lands, prey availability explained the use of road verges by polecats (Barrientos \& Bolonio, 2009).

Polecats are regarded as generalist feeders but, according to Lodé (1997), they might specialise locally on a particular food resource such as rodents, amphibians or wild rabbits. This seems to be the case in southeast Portugal, where diet analysis revealed a specialisation towards lagomorphs, most probably wild rabbits (Santos et al., 2009). The authors expected to find an adjustment of polecat behaviour and ecological traits to long-term anthropogenic pressures, as observed in other carnivore species (Rosalino et al., 2005; Rosalino \& Santos-Reis, 2008; Loureiro et al., 2009). However, instead of opportunistically selecting food resources in response to seasonal variation of prey, polecats maintained their preference for lagomorphs and showed a spatial arrangement around areas where wild rabbits were abundant, which could explain the fragmented distribution of the species in the region (Santos et al., 2009). These results are concordant with data from Spain (Virgós, 2007; Barrientos \& Bolonio, 2009) and underline the importance of wild rabbit presence in polecat distribution and abundance.

Data on feeding ecology of polecat populations is absent or unreliable elsewhere in Portugal. For instance, a study carried out in the Peneda-Gerês National Park (northwest Portugal), compared the diet of four carnivore species, including the polecat (Gomes, 1988). However, the author was forced to pool the polecat and the stone marten together in the analyses, due to difficulties in distinguishing reliably the scats of the two species. Mammalian species occurred with a frequency of more than $80 \%$ in the diet of the two species combined, but no evidence was found for the presence of lagomorphs. These results are likely biased due to differences in habitat preference, behaviour and ecological strategies of the two species involved (Santos-Reis et al., 2005).

Florêncio (1993) conducted a study about the importance of the invasive red swamp crayfish Procambarus clarkii (Girard, 1852) as a food resource for the carnivore community of the Paúl do Boquilobo Natural Reserve (central Portugal). The author stated that this natural reserve provides conditions for polecat occurrence and, although only a few polecat scats were detected during the study, the species was considered abundant in the area based on a number of direct sightings. The diet analysis, which only considered broad categories of prey, found that mammalian species composed more than $90 \%$ of the polecat diet. The role of the red swamp crayfish as prey for the carnivore community also motivated the study of Correia (2001), who found no signs of the species in the diet of the polecat.

Amphibians, a known prey in other areas of the polecat range (Lodé, 2000; Baghli et al., 2002), were not detected in any of the above-mentioned studies, which could be explained by the low number of samples analysed or by geographic differences in prey preferences.

\section{Conservation threats}

In Portugal, the suspected decline in polecat numbers probably results from a combination of several factors, such as habitat degradation due to agricultural intensification, decreasing prey populations, direct persecution, and road mortality (Cabral et al., 2005). Secondary poisoning, the use of non-selective methods for predator control, and hybridisation with feral ferrets, may also represent threats to the species in Portugal, as they have been described to affect polecat populations elsewhere (Birks, 1998; Davison et al., 1999; Packer \& Birks, 1999; Shore et al., 2003; Konjeviç, 2005; Costa et al., 2013).

Due to its strong association with wetlands, the polecat is vulnerable to threats to these habitats (Santos-Reis \& Mathias, 1996). Habitat fragmentation and suppression of ecological corridors can lead to the isolation of populations, decreasing genetic diversity and hence the potential for adaptation to environmental change, which in turn increases the probability of extinction (Frankham et al., 2002). In southern Portugal, where water is often a limiting factor, particularly for agricultural practices, the construction of dams is responsible for the loss of suitable habitats (Mestre et al., 2007). For example, the construction of the Alqueva dam not only resulted in the destruction of riparian vegetation but also flooded important areas for the species and reduced prey and shelter availability (Santos et al., 2008).

The specialised diet of the polecat observed in the aforementioned studies suggests that the future of its populations in the agricultural landscapes of southern Portugal might be compromised if anthropogenic pressures persist. For instance, Santos et al. (2009) stated that the recovery of fragmented polecat populations could be hampered by the combined effect of the decline in wild rabbit numbers, caused by epizootic diseases (myxomatosis and haemorrhagic fever - Calvete, 1999; Mutze et al., 2002) and overexploitation by hunters.

The polecat was formerly widely hunted for sport and its fur, and persecuted as poultry-killer. In Britain, by the end of the 19th century, the polecat had been eradicated from most of its range, as a result of the development of sporting estates and persecution by gamekeepers (Birks \& Kitchener, 1999; Birks, 2000). However, due to its current legal protection under European legislation (e.g. EU Habitat Directive), rates of hunting and persecution have been reduced across most of the species range (Fernandes et al., 2008b).

Road mortality is one of the most visible anthropogenic impacts on wildlife communities, threatening biodiversity conservation, especially when populations already occur in low numbers (Forman \& Alexander, 1998). In Portuguese roads, polecats have been recorded as being one of several vertebrate species affected by road collisions (Grilo et al., 2007, 2009; Carvalho \& Mira, 2010). The lower number of records for polecats, compared to other carnivore species, may be explained by low polecat densities in the area (Grilo et al., 2009) or by the fact that polecats may be less prone to road mortality due to road avoidance (Grilo et al., 2008). However, polecats seem to be affected by 
high road and traffic densities, particularly in human-disturbed areas (Santos et al., 2008). Road mortality may be related to hunting tactics of polecats on road verges, juvenile dispersal, and mating behaviour (Barrientos \& Bolonio, 2009). Ultimately, the increase of the road network density could represent major barriers to gene flow between polecat populations, which again will be reflected in a lower capacity to respond to environmental change.

Polecats might be prone to contamination through pollutant bioaccumulation and accidental poisoning with rodenticides (Birks, 1998, 2000; Shore et al., 2003). To our knowledge, no studies assessed the impact of pesticides on polecat populations in Portugal, but this has been shown to be one of the threats to otters in the country (Trindade et al., 1998). Semi-aquatic carnivores are particularly vulnerable to toxin accumulation through the aquatic food web (Lodé et al., 2001), and this is a potential cause for the decline of polecat populations. Although polecats are not strongly associated with farmyards in Portugal, the risk of primary or secondary poisoning by anticoagulant rodenticides still needs to be investigated. Data from the Programa Antídoto - Portugal shows no record of polecats among the 1534 poisoned animals found between 2003 and 2013 (Brandão, 2013). However, records of poisoned animals depend on species abundance, feeding habits and detectability (Lozano et al. 2010), and thus this issue should be considered in future studies of the species.

In Portugal, although the polecat is not considered a game species, as is the case of the red fox Vulpes vulpes (Linnaeus, 1758) or the Egyptian mongoose Herpestes ichneumon (Linnaeus, 1758) (Decree-Law $n^{\circ}$ 201/2005), the fact is that there is no available data regarding the number of polecats captured during predator control activities allowed by law, but which may use non-selective traps. Without law enforcement to police these practices on the ground it is difficult to determine the real impact of these activities on polecat populations

Hybridisation between polecats and other mustelid species has been reported to occur in nature (Davison et al., 1999; Lodé et al., 2005; Cabria et al., 2011; Costa et al., 2013). Although rare, hybridisation with the European mink Mustela lutreola (Linnaeus, 1761) seems to pose a major threat for mink populations that are more depleted locally than polecat populations (Lodé et al., 2005; Cabria et al., 2011). In Britain, current hybridisation with ferrets does not seem to be a cause for concern, but it was significant in the recent past during and subsequent to the polecat demographic decline of the 19th century and prevents the reliable identification of "pure polecats" solely based on morphological characteristics (Davison et al., 1999; Costa et al., 2013). In Portugal, legislation regarding ferret ownership is ambiguous. In the past, only hunting associations with special permits were allowed to maintain these animals (Decree-Law no 201/2005), although more recently there has been some attempt to regulate the keeping of ferrets also as pets (Ordinance $n-7 / 2010$ ). To our knowledge, there are no records of established feral ferret populations in mainland Portugal, but some animals are likely to escape during hunting campaigns or be abando- ned by their owners. Ferrets are occasionally found in road mortality studies but their origin has never been investigated. As illustrated by the case of the Portuguese Atlantic islands (Mathias et al., 1998), in the absence of competition ferrets are able to persist in the wild, but their survivorship and whether they hybridise with polecats in continental Portugal are issues that still need to be addressed. An ongoing genetic study aims to shed some light on the impact of hybridisation with ferrets on the polecat in Portugal (Costa et al., unpubl.). However, the morphological features observed on the road-killed animals used in the study suggest that hybridisation with ferrets does not currently pose a serious threat to the Portuguese polecat, since they all exhibited the wild phenotype.

\section{PROSPECTS AND CHALLENGES}

\section{Future research}

As presented above, information about the polecat in Portugal is scarce and basic knowledge is needed in order to understand the current state of its populations in the country and carry out management actions accordingly. The more pressing issue is establishing an accurate occurrence map for the species. This can be done by setting up a collaborative network to collect new data nationwide, using a standard monitoring protocol, and creating a database on the presence of the species, as suggested by Matos et al. (2001). Future monitoring programmes should use combined methodologies to ascertain polecat presence, such as detection of footprints and scats, genetic species identification of scats, collection of road-killed animals, and live- and camera-trapping campaigns. An example of a successful countrywide effort of this kind can be taken from Britain where two national polecat surveys, relying mainly on work from volunteers, were conducted in 1993-1997 (Birks \& Kitchener, 1999) and 2004-2006 (Birks, 2008). Road-kills represented, respectively, $68 \%$ and $77 \%$ of all records in each survey and a high percentage of these records (44\% and $73 \%$ ) were verified by direct examination of the animal or through photographs. The first survey also included live-trapping sessions, followed by radio-tracking. A similar volunteer-based approach could be applied in Portugal to increase the number of records throughout the country in a cost-effective manner. Once a distribution baseline is established, live-, camera- and hairtrapping can be employed in areas with a high density of preliminary records, as they are powerful methods for ascertaining species presence and provide samples for genetic analyses. In association with camera- and hair-traps we suggest the use of attractants, namely Eurasian lynx Lynx Iynx (Linnaeus, 1758) urine and valerian-extract solution, since it originates investigative behaviours from captive polecats (Monterroso et al., 2011). After methodological optimisation in the field, these techniques can subsequently be applied to other areas comprising suitable habitat for the species.

Future research on the polecat in Portugal should also aim to determine population size and structure, local abundance, sex ratio, dispersal rates, and expand incipient kno- 
wledge on the use of time and space by the species (Manghi et al., 2005). Moreover, Matos et al. (2001) highlighted the importance of: (1) analysing variations in diet according to prey availability; (2) map the presence and abundance of wild rabbits in areas of polecat occurrence; (3) evaluate barrier effects in fragmented populations; (4) develop predictive models of potential distribution and habitat suitability; and (5) assess the impacts of the construction of new infrastructures (e.g. roads, dams) and of agricultural intensification in polecat populations.

There is a need for research on the less studied polecat populations of the centre and north of Portugal, areas in which ecological requirements of the species are likely to differ from the ones observed in the south, as differences in environmental conditions along the country are likely reflected on habitat and prey availability. The study by Rodrigues et al., 2014) in northwest Portugal, aiming to understand the interspecific interactions between polecats, otters and American minks opens the way for additional studies in the region. The introduction of the American mink has been pointed out as one of the main causes for the rapid decline of European mink populations in Europe (Maran et al., 1998), and could also affect polecat abundance and distribution through competition over resources and/or as a result of American mink aggressive behaviour regardless of resource use (Sidorovich et al., 2000).

We are currently investigating the genetic structure of the Portuguese polecat, and putative hybridisation with ferrets, using samples (mostly from road-kills) collected since 2000 and a panel of 12 microsatellites developed by us (Costa et al., 2012). This panel, which includes nine novel loci isolated in the polecat, has been used in a recent genetic study on the British polecat (Costa et al., 2013) and should be useful for future genetic studies of polecats, ferrets and their hybridisation in Portugal and elsewhere.

\section{Conservation guidelines}

At the moment there is no National Species Conservation Action Plan specific for the polecat in Portugal, but the Institute for Nature Conservation has proposed some general guidelines (SIPNAT, 2009) for the conservation of the species. These guidelines stem from the known threats to polecat populations and include habitat protection, maintenance of the heterogeneity of rural landscapes, and surveillance of predator control activities and of hybridisation with domestic ferrets. Although the latter has not yet been detected in Portugal, measures should be taken to prevent the release or escape of fertile ferrets into the wild. Cabral et al. (2005) also emphasised the importance of raising public awareness and understanding towards polecats, as a generally negative image of carnivores still persists in our culture.

Conservation actions should primarily be focused on the preservation and/or restoration of suitable habitats for the species, with a special emphasis on riparian systems (Mestre et al., 2007; Matos et al., 2009). Moreover, the establishment of ecological corridors, such as hedgerow networks and small areas of scrubs, will enhance con- nectivity between habitat patches in fragmented landscapes (Mestre et al., 2007). In agricultural landscapes, non-intensive farming should be encouraged, with natural vegetation maintenance and restricted use of pesticides. In this context, we also suggest the implementation of a programme of ecotoxicological screening of road-killed animals to monitor contamination by rodenticides.

In southern Portugal, priority should also be given to the recovery and preservation of wild rabbit populations, the polecat's main prey, through improvement of habitat quality and implementation of restocking and immunisation programs (Santos et al., 2009). Habitat improvement actions, especially the installation of crops, seem to have contributed significantly to wild rabbit abundance in Serra de Monchique (Encarnação, 2009).

Concerning polecat road mortality, mitigation measures can be implemented in order to reduce the amount of collisions. Culverts and highway underpasses are often used by carnivores to cross roads and can be vital in maintaining landscape connectivity (Grilo et al., 2008). To increase the probability of usage by carnivores, Grilo et al. (2008) recommended several measures to be considered by highway managers: (1) construction of large passages; (2) prioritise mitigation measures in areas with ecological significance for carnivores (e.g. natural forest areas and sites with streams and riparian vegetation); (3) planting vegetation at passage entrances, to guide animals towards existing structures; and (4) restrict human use of passages. However, these structures proved to be selectively permeable, and not all species used them. Polecats showed road avoidance possibly due to its specific habitat preferences and antagonism towards artificial structures (Ascenção \& Mira, 2007; Grilo et al., 2008). To tackle this problem, Grilo et al. (2008) also suggested the maintenance of natural structures inside the passage, such as soil, logs, rocks, and woody debris.

Due to the use of non-selective traps in predator control, polecats might be frequent victims of these methods and it is therefore essential that the law enforcement authorities police such activities. There is also the need to reduce the conflict between polecat predation and game management. Mitigation of the impact of predator control methods in polecat populations can be achieved by enhancing the design of the commonly used traps to prevent the non-target capture of polecats, whereas improvements in husbandry practices could prevent the access of polecats to game and poultry (Packer \& Birks, 1999).

Before generalised application, some of the aforementioned management and conservation measures could be implemented at specific sites and monitored and evaluated to test their effectiveness.

As pointed out above, most studies performed to date were carried out in southern Portugal, with the authors suggesting specific management measures that should contribute to polecat conservation in the study areas. More studies covering a broader geographical scale are needed in order to provide conservation autho- 
rities with crucial information relevant to the development of management action plans at the national level. At any rate, considering the available data reviewed here, we argue that the conservation status of the polecat in Portugal needs to be re-evaluated and that it might be found that the species is now near threatened in the country.

\section{ACKNOWLEDGEMENTS}

We thank Mafalda Basto and Nuno M. Pedroso for revisions of this chapter and Victoria San Andrés for the Spanish translation of the Abstract. We also acknowledge financial support from the Portuguese Science Foundation to M.C. (PhD fellowship SFRH/BD/32488/2006), C.F. (FCTMCTES; contract C2007-UL-342-CBA1) and M.S.R./C.F. (Research Contract: PTDC/BIA-BEC/102433/2008). This study was supported by Centro de Biologia Ambiental (PEst-OE/BIA/UI0329/2011).

\section{BIBLIOGRAPHY}

Ascenção, F., Mira, A. 2007. Factors affecting culvert use by vertebrates along two stretches of road in southern Portugal. Ecol. Res. 22: 57-66.

Baghli, A., Engel, E., Verhagen, R. 2002. Feeding habits and trophic niche overlap of two sympatric Mustelidae, the polecat Mustela putorius and the beech marten Martes foina. Z. Jagdwiss. 48: $217-225$

Barrientos, R., Bolonio, L. 2009. The presence of rabbits adjacent to roads increases polecat road mortality. Biodivers. Conserv. 18: 405-418.

Beja, P., Espírito-Santo, C., Pedroso, N. 2005. Estudos complementares do Plano de Ordenamento do Tejo Internacional - Comunidades de Carnívoros. ERENA e CARNIVORA. Lisboa.

Beja, P., Gordinho, L., Loureiro, F., Santos-Reis, M., Borralho, R. 2009. Predator abundance in relation to small game management in Southern Portugal: conservation implications. Eur. J. Wildl. Res. 55: 227-238.

Birks, J.D.S. 1998. Secondary rodenticide poisoning risk arising from winter farmyard use by the European polecat Mustela putorius. Biol. Conserv. 85: 233-240.

Birks, J.D.S. 2000. The recovery of the polecat, Mustela putorius, in Britain. In: Mustelids in a modern world - Management and conservation aspects of small carnivore: human interactions. H.I. Griffiths (Ed): 141-152. Backhuys Publishers. Leiden.

Birks, J.D.S. 2008. The polecat survey of Britain 2004-2006: A report on the Polecat's distribution, status and conservation. The Vincent Wildlife Trust. Ledbury.

Birks, J.D.S., Kitchener A.C. 1999. The distribution and status of the polecat (Mustela putorius) in Britain in the 1990s. The Vincent Wildlife Trust. London.

Blandford, P.R. 1987. Biology of the polecat Mustela putorius: a literature review. Mammal Rev. 17: 155-198.

Bocage, J.B. 1863. Liste des Mammifères et Reptiles observes en Portugal. Rev. Mag. Zool. Pure Appl. 5: 329-333.

Brandão, R.M.L. 2013. Uso ilegal de venenos: toxicologia, protocolos de actuação e aspectos legais. Associação ALDEIA / Programa Antídoto - Portugal. Encontro Científico Estudo e Conservação do Lobo Ibérico. Sabugal. 12th July.
Cabral, M.J., Almeida, J., Almeida, P.R., Dellinge, T., Ferrand de Almeida, N., Oliveira, M.E., Palmeirim, J.M., Queiroz, A.I., Rogado, L., Santos-Reis, M. (Ed.). 2005. Livro Vermelho dos Vertebrados de Portugal. Instituto da Conservação da Natureza. Lisboa.

Cabria, M.T., Michaux, J.R., Gómez-Moliner, B.J., Skumatov, D. Maran, T., Fournier, P., López de Luzuriaga, J., Zardoya, R. 2011. Bayesian analysis of hybridization and introgression between the endangered european mink (Mustela lutreola) and the polecat (Mustela putorius). Mol. Ecol. 20: 1176-1190.

Calvete, C. 1999. Epidemiología de enfermedad hemorrágica (VHD) y mixomatosis en el conejo silvestre en el valle medio del Ebro. Modelización de VHD y herramientas de gestión. Tesis Doctoral. Facultad de Veterinaria de Zaragoza. Zaragoza.

Carvalho, F., Mira, A. 2010. Comparing annual vertebrate road kills over two time periods, 9 years apart: a case study in Mediterranean farmland. Eur. J. Wildl. Res. 57: 157-174.

Chambel, I., Mota, M., Rodrigues, M., Santos-Reis, M. 2001. Inventariacão de Mamíferos Não Voadores na Area da Paisagem Protegida da Arriba Fóssil da Costa de Caparica. Relatório Final. Faculdade de Ciências da Universidade de Lisboa. Lisboa.

Correia, A.M. 2001. Seasonal and interspecific evaluation of predation by mammals and birds on the introduced red swamp crayfish Procambarus clarckii (Crustacea, Cambaridae) in a freshwater marsh (Portugal). J. Zool. 255: 533-541.

Costa, M., Fernandes, C., Birks, J.D.S., Kitchener, A.C., SantosReis, M., Bruford, M.W. 2013. The genetic legacy of the 19th-century decline of the British polecat: evidence for extensive introgression from feral ferrets. Mol. Ecol. 22: 5130-5147.

Costa, M., Fernandes, C., Rodrigues, M., Santos-Reis, M., Bruford, M.W. 2012. A panel of microsatellite markers for genetic studies of European polecats (Mustela putorius) and ferrets (Mustela furo). Eur. J. Wildl. Res. 58: 629-633.

Davison, A., Birks, J.D.S., Griffiths, H.I., Kitchener, A.C., Biggins, D., Butlin, R.K. 1999. Hybridization and the phylogenetic relationship between polecats and domestic ferrets in Britain. Biol. Conserv. 87: 155-161.

Encarnação, C. 2009. Influência da gestão do habitat na distribuição e abundância do coelho-bravo no Sítio Natura 2000 de Monchique. Tese de Mestrado. Universidade de Évora. Évora.

Fernandes, C., Ginja, C., Pereira, I., Tenreiro, R., Bruford, M.W., Santos-Reis, M. 2008a. Species-specific mitochondrial DNA markers for identification of non-invasive samples from sympatric carnivores in the Iberian Peninsula. Conserv. Genet. 9: 681-690.

Fernandes, M., Maran, T., Tikhonov, A., Conroy, J., Cavallini, P. Kranz, A., Herrero, J., Stubbe, M., Abramov, A., Wozencraft, C. 2008b. Mustela putorius. In: IUCN 2010. IUCN Red List of Threatened Species. Version 2010.4. <www.iucnredlist.org>. Downloaded on 1st May 2013

Florêncio, E. 1993. O lagostim do rio (Procambarus clarkii Girard, 1852) como recurso alimentar da comunidade de carnívoros na Reserva Natural do Paúl do Boquilobo. Relatório de estágio profissionalizante para obtenção da Licenciatura em Recursos Faunísticos e Ambiente. Faculdade de Ciências da Universidade de Lisboa. Lisboa.

Forman, R.T., Alexander, L.E. 1998. Roads and their major ecological effects. Annu. Rev. Ecol. Evol. Syst. 29: 207-231.

Frankham, R., Ballou, J., Briscoe, D. 2002. Introduction to conservation genetics. Cambridge University Press. New York.

Gomes, P. 1988. Análise da estrutura trófica de uma comunidade de mamíferos: estudo comparativo do regime alimentar de três tipos de predadores (raposa geneta e complexo toirão/fuinha) no Parque Nacional da Peneda-Gerês. Provas de Aptidão Pedagógica e Capacidade Científica. Universidade do Minho. Braga. 
Grilo, C., Bissonette, J., Santos-Reis, M. 2008. Response of carnivores to existing highway culverts and underpasses: implications for road planning and mitigation. Biodivers. Conserv. 17: 1685-1699.

Grilo, C. Bissonette, J., Santos-Reis, M. 2009. Spatial-temporal patterns in Mediterranean carnivore road casualties: consequences for mitigation. Biol. Conserv. 142: 301-313.

Grilo, C., Silva, C., Baltazar, C., Gomes, L., Bissonette, J., SantosReis, M. 2007. Patterns of carnivore road casualties in Southern Portugal. Proceedings of the 2007 International Conference on Ecology \& Transportation 'Bridging The Gaps, Naturally'. Little Rock, Arkansas. 20th-25th May.

Gu, W. Swihart, R.K. 2004. Absent or undetected? Effects of nondetection of species occurrence on wildlife-habitat models. Biol. Conserv. 116: 195-203.

Konjević, D. 2005. The European polecat (Mustela putorius Linnaeus, 1758) in Croatia - management concerns. Natura Croatica 14: 39-46.

Lodé, T. 1993. Stratégies d'utilisation de l'espace chez le Putois européen Mustela putorius $L$. dans le oust de la France. Rev. d'Ecologie (Terre Vie) 48: 305-322.

Lodé, T. 1994. Environmental factors influencing habitat exploitation by the polecat Mustela putorius in western France. J. Zool. $234: 75-88$.

Lodé, T. 1997. Trophic status and feeding habits of the European Polecat Mustela putorius L. 1758. Mammal Rev. 27: 177-184.

Lodé, T. 2000. Functional response and area-restricted search in a predator: seasonal exploitation of anurans by the European polecat, Mustela putorius. Austral Ecol. 25: 223-231.

Lodé, T., Cormier, J.P., Jacques, D. 2001. Decline in endangered species as an indication of anthropic pressures: the case of European mink Mustela lutreola western population. Environ. Manag. 28: 727-735.

Lodé, T., Guiral, G., Peltier, D. 2005. European mink-polecat hybridization events: hazards from natural process? J. Hered. 96 89-96.

Loureiro, F., Bissonette, J.A., Macdonald, D.W., Santos-Reis, M. 2009. Temporal variation in the availability of Mediterranean food resources: do badgers Meles meles track them? Wildl. Biol. 15: 197-206

Loureiro, F., Sousa, M., Basto, M., Pedroso, N., Rosário, J., SalesLuís, T. Chambel, I., Rosalino, L.M. 2007. A comunidade de mamíferos não voadores da Paisagem Protegida da Serra de Montejunto (Centro de Portugal): distribuição e situação regional. Galemys 19: 139-157.

Lozano, J., Virgós, E., Mangas, J.G. 2010. Veneno y control de predadores. Galemys 22: 123-132.

Manghi, G., Costa, M., Pereira, D., Mira, A. 2005. Area vital y patrones de actividad del turon (Mustela putorius) en el sur de Portugal. Datos preliminares. VII Jornadas de la SECEM. Valencia. $3^{\text {rd }-6^{\text {th }}}$ December. Poster presentation.

Maran, T., Macdonald, D.W., Kruuk, H., Sidorovich, V., Rozhnov, V.V. 1998. The continuing decline of the European mink Mustela lutreola: evidence for the intraguild aggression hypothesis. In: Behaviour and ecology of riparian mammals. N. Dunston, M.L. Gorman (Ed.): 297-323. Symposium of the Zoological Society of London, 71. Cambridge University Press. Cambridge.

Mateus, A.R., Grilo, C., Santos-Reis, M. 2010. Surveying drainage culvert use by carnivores: sampling design and cost-benefit analyzes of track-pads vs. video-surveillance methods. Environ. Monit. Assess. 181: 101-109.
Mathias, M.L., Ramalhinho, M.G., Santos-Reis, M., Petrucci-Fonseca, F., Libois, R., Fons, R., Ferrez de Carvalho, G., Oom, M.M. Collares-Pereira, M.J. 1998. Mammals from Azores islands (Portugal): na update overview. Mammalia 62: 397-407.

Matos, H., Santos, M.J., Grilo, C., Sousa, I., Santos-Reis, M. 2001. Estudos de biologia e ecologia do toirão Mustela putorius na área de regolfo de Alqueva e Pedrógão. Relatório Técnico Final (Programa de Minimização para o Património Natural). Centro de Biologia Ambiental (FCUL). Lisboa.

Matos, H., Santos, M.J., Palomares, F., Santos-Reis, M. 2009 Does riparian habitat condition influence mammalian carnivore abundance in Mediterranean ecosystems? Biodivers. Conserv. 18: 373-386.

Matos, H. Santos-Reis, M. 2003. Distribuição actual e abundância relativa de Martes martes e Mustela putorius. Relatório Final. Estudo integrado no Projecto do ICN "Livro Vermelho dos Vertebrados de Portugal - Revisão", Programa Operacional do Ambiente. Centro de Biologia Ambiental (FCUL). Lisboa.

Mestre, F.M., Ferreira, J.P., Mira, A. 2007. Modelling the distribution of the European polecat Mustela putorius in a Mediterranean agricultural landscape. Rev. d'Ecologie (Terre Vie) 62: 35-47.

Monterroso, P., Alves, P.C., Ferreras, P. 2011. Evaluation of attractants for non-invasive studies of lberian carnivore communities. Wildl. Res. 38: 446-454.

Monterroso, P., Castro, D., Silva, T.L., Ferreras, P., Godinho, R. Alves, P.C. 2013. Factors affecting the (in)accuracy of mammalian mesocarnivore scat identification in South-western Europe. J. Zool. 289: 243-250

Mutze, G., Bird, P., Kovaliski, J., Peacock, D., Jenning, S., Cooke, B. 2002. Emerging epidemiological patterns in rabbit haemorrhagic disease, its interaction with myxomatosis, and their effects on rabbit populations in South Australia. Wildl. Res. 29: 577-590.

Oliveira, R., Castro, D., Godinho, R., Luikart, G., Alves, P.C. 2010 Species identification using a small nuclear gene fragment: application to sympatric wild carnivores from South-western Europe. Conserv. Genet. 11: 1023-1032.

Packer, J.J., Birks, J.D.S. 1999. An assessment of British farmers' and gamekeepers' experiences, attitudes and practices in relation to the European Polecat Mustela putorius. Mammal Rev. 29 75-92.

Paupério, J., Monterroso, P., Rebelo, H., Moreira, P., Castro, D. Silva, A., Alves, P.C. 2008. Avaliação do estado actual do conhecimento dos mamíferos no Parque Natural do Douro Internacional. Relatório Final. Centro de Investigação em Biodiversidade e Recursos Genéticos (CIBIO/ICETA-UP). Instituto de Conservacão da Natureza e da Biodiversidade. Parque Natural do Douro Internacional (ICNB/PNDI). Vairão.

Pita, R., Mira, A., Moreira, F., Morgado, R., Beja, P. 2009. Influence of landscape characteristics on carnivore diversity and abundance in Mediterranean farmland. Agric., Ecosyst. Environ. 132: 57-65.

Rodrigues, D., Moreira, M., Simões, L., Lampa, S., Fernandes, C. Rebelo, R. Santos-Reis, M. 2014. Tracking the expansion of the American mink (Neovison vison) range in NW Portugal. Biol. Invasions (online 4 may) Doi 10.1007/s10530-014-0706-1

Rondinini, C., Ercoli, V., Boitani, L. 2006. Habitat use and preference by polecats (Mustela putorius $L$.) in a Mediterranean agricultural landscape. J. Wildl. Zool. 269: 213-219.

Rosalino, L.M., Loureiro, F., Macdonald, D.W., Santos-Reis, M. 2005. Dietary shifts of the badger Meles meles in Mediterranean woodlands: an opportunistic forager with seasonal specialisms. Mamm. Biol. 70: 12-23.

Rosalino, L.M., Santos-Reis, M. 2008. Fruit consumption by carnivores in Mediterranean Europe. Mammal Rev. 39: 67-78. 
Santos, M.J., Matos, H.M., Baltazar, C., Grilo, C., Santos-Reis, M. 2009. Is Polecat (Mustela putorius) diet affected by "mediterraneity"? Mamm. Biol. 74: 448-458.

Santos, M.J., Pedroso, N., Ferreira, J.P., Matos, H., Sales-Luís, T., Pereira, I. Baltazar, C. Grilo, C. Cândido, A.T., Sousa, I., SantosReis, M. 2008. Assessing dam implementation impact on threatened carnivores: the case of Alqueva in SE Portugal. Environ. Monit. Assess. 142: 47-64.

Santos-Reis, M. 1983. Status and Distribution of the Portuguese Mustelids. Acta Zool. Fenn. 174: 213-216.

Santos-Reis, M., Mathias, M.L. 1996. The historical and recent distribution and status of mammals in Portugal. Hystrix 8: 75-89.

Santos-Reis, M., Rosalino, L.M., Rodrigues, M. 1999. Lagomorfos, Carnívoros e Artiodáctilos (Mamíferos). In: Caracterização da Flora e Fauna do Montado da Herdade da Ribeira Abaixo (Grândola-Baixo Alentejo). M. Santos-Reis, A.I. Correia (Ed.): 249-262. Centro de Biologia Ambiental (FCUL). Lisboa.

Santos-Reis, M., Santos, M., Lourenço, S., Marques, J., Pereira, I. Pinto, B. 2005. Relationships between Stone Martens, Genets and Cork Oak Woodlands in Portugal. In: Martens and Fishers (Martes) in human-altered environments Part II. D. Harrison, A. Fuller, G Prouxl (Ed.): 147-173. Kluwer Academic Publishers. Dordrecht.

Seabra, A.F. 1900. Mamíferos de Portugal no Museu de Lisboa. Jornal das Sciencias Mathematicas, Physicas e Naturaes 6: 90-115.

Shore, R.F., Birks, J.D.S., Afsar, A., Wienburg, C.L., Kitchener, A.C. 2003. Spatial and temporal analysis of second-generation anticoagulant rodenticide residues in polecats (Mustela putorius) from throughout their range in Britain, 1992-1999. Environ. Pollut. 122: $183-193$.

Sidorovich, V.E., Macdonald, D.W., Kruuk, H., Krasko, D.A. 2000. Behavioural interactions between the naturalized American mink Mustela vison and the native riparian mustelids, $\mathrm{Ne}$ Belarus, with implications for population changes. Small Carniv. Conserv. 22: 1-5.
SIPNAT - Sistema de Informação do Património Natural. 2009 Caracterização das Espécies - Mustela putorius. Instituto da Conservação da Natureza e das Florestas (ICNF) <http://www.icn.pt/sipnat/>. Downloaded on 1st May 2013.

SNPRCN. 1990. Livro Vermelho dos Vertebrados de Portugal. Vol. I - Mamíferos, Aves, Répteis e Anfíbios. SNPRCN. Lisboa.

Syfert, M., Smith, M.J., Coomes, D.A. 2013. The Effects of Sampling Bias and Model Complexity on the Predictive Performance of MaxEnt Species Distribution Models. PloS ONE 8: e55158.

Trindade, A., Farinha, N., Florêncio, E. 1998. A distribuição da Lontra (Lutra lutra) em Portugal - Situação de 1995. Instituto da Conservação da Natureza/Divisão de Espécies Protegidas/Programa Life. Lisboa.

Vandelli, D. 1787. Florae et Faunae Lusitanicae Specimen. Memorias da Academia Real das Sciencias de Lisboa. 1: 37-49.

Virgós, E. 2001. Relative value of riparian woodlands in landscapes with different forest cover for medium-sized Iberian carnivores. Biodivers. Conserv. 10: 1039-1049.

Virgós, E. 2002. Mustela putorius Linnaeus, 1758. In: Altas de los Mamíferos Terrestres de España. L. Palomo, J. Gisbert (Ed.): 262-265. Sociedad Española de Ornitologia (SEO/BirdLife). Museo Nacional de Ciencias Naturales (CSIC). Universidad de Málaga. Madrid.

Virgós, E. 2003. Association of the polecat Mustela putorius in eastern Spain with montane pine forests. Oryx 37: 484-487.

Virgós, E. 2007. Mustela putorius Linnaeus, 1758. In: Atlas y Libro Rojo de los Mamíferos Terrestres de España. L. Palomo, J. Gisbert, J.C. Blanco (Ed.): 294-296. Dirección General para la Biodiversidad-SECEM-SECEMU. Madrid.

Zabala, J., Zubergoitia, I., Martínez-Climent, J.A. 2005. Site and landscape features ruling the habitat use and occupancy of the polecat (Mustela putorius) in a low density area: a multiscale approach. Eur. J. Wildl. Res. 51: 157-162. 